\title{
Hopes and fears in the Future Orientation of Emerging Adults: Implications for dependable and productive adult futures in Cameroon
}

\author{
Joseph Lah Lo-oh \\ The University of Bamenda, Faculty of Education, PO Box 39 Bambili, NW Region, Cameroon \\ Email: ljosephlah@yahoo.com
}

\begin{abstract}
Emerging adulthood is a time of transition when young people actively work to define themselves and their future roles in preparation for full adult status. It is a time of making critical life decisions to shape the course of their adult lives either in education, career and life-style. Albeit these, those raised in impoverished environments as those in most of Africa, are at substantial risk of making poor life decisions because among others, they are often exposed to difficult life circumstances. Navigating future life courses becomes an arduous task accompanied by very difficult conditions, leaving most emerging adults hopeless about the future of their lives. As such, their future orientations appear quite uncertain, contestable and mixed between hopes and fears; and pathways marked by a litany of challenges. This article presents data on hopes and fears in the future orientation of emerging adults, collected with the Hopes and Fears Questionnaire among 137 final year undergraduates, aged 18-26 in Cameroon. Descriptive analyses show twin orientations towards future identities: hopes and fears as well as education, work and family as key routes to adulthood. While a significant proportion hope for, among others, work and career development (75.9\%), marriage and family formation $(56 \%)$, and schooling or continuing education (38.7\%); they also fear not continuing their education because of no funding (67\&), loosing sponsorship, becoming unemployed and poor $(52.6 \%)$, not getting married and having children of their own (40\%), and so on. Meanwhile $85.4 \%$ feel that education, work and marriage are dependable pathways to hopeful and productive futures. These findings showed that the tendency to think about the future is well developed among Cameroon emerging adults; and like in most of the literature, their images of the future are caught between hopes and fears. Comparatively however, the Cameroon data suggest that pessimistic visions of the future of adulthood are more developed and expansive than optimistic futures where respondents are more skeptical about their futures. This may be true given the harsh realities of growing up in Cameroon today. Like in previous studies the road to adulthood is socially constructed and institutionalised with pathways delineated by completing school, leaving home, beginning one's career, marrying, and becoming a parent. This is acceptable data in Cameroon given its "still strongly acclaimed" sociological and demographic definitions of adulthood.
\end{abstract}

Keywords: Hopes. Fears, Future orientation, Emerging adults, Dependable futures, Productive futures

DOI: $10.7176 / \mathrm{DCS} / 11-7-07$

Publication date:September $30^{\text {th }} 2021$

\section{Introduction}

Adolescence and emerging adulthood is a time of transition when youth actively work to define themselves and their future roles in preparation for full adulthood. In this light, and for many developmental psychologists, the period is seen as a time of preparation for adulthood (Call, Reidel, Hein, McLoyd, Peterson \& Kipke, 2002). During this stage, youth begin to make critical life decisions that shape the course of their adult lives (e.g., education, career, and life-style). In this light, adolescents raised in difficult circumstances and in impoverished environments are at elevated and substantial risk of making poor life decisions and transitions since they are often exposed to high levels of neighbourhood violence and substance use, and are more likely to attend underresourced schools (Broomfield, 2007). While school-to-work transitions are typically long and difficult, poverty and large income shocks often push children into the work force (Garcia \& Fares, 2008). Despite facing these risks, many affected youth experience adaptive developmental outcomes in the face of these challenges. Many of them in spite of the challenges strive for excellence and through agentic and resilient behaviours, they record successes and become dependable, functional and productive in their lives and community. They become more positively oriented towards, dependable positive and productive futures. Resilience literature identifies the presence of a supportive adult relationship and a positive future orientation (i.e., an optimistic conceptualization of the future) as factors related to decreases in negative outcomes and increases in positive outcomes among youth exposed to conditions of risk (Becker \& Luthar, 2002). For instance, having a supportive relationship with an adult has been linked to more positive future orientation, increased educational success and decreased delinquency and substance use (Steinberg, 2001). Similarly, future orientation is positively associated with academic achievement, delaying sex or abstaining from it, and later upward mobility (Seginer, 2009). Future 
orientation is also negatively associated with sensation seeking, substance use, and aggression (Somers \& Gizzi, 2001).

Underlying this literature is the assumption that adolescents are being groomed and shaped, intentionally and unintentionally, for the roles they will take on in the future. Multiple systems are involved in this preparation and orientation, resulting in a complex process which operates to propel adolescents toward thinking about and making plans for later adult attainments. Through this process, adolescents should gain experiences that help them shape their own expectations of the future, which include perceptions of possibilities and opportunities (Nurmi, 2004); and also fears that they must deal with or avoid as they look up to the future. These expectations will impact their decisions and the opportunities they pursue, placing them on trajectories that shape the rest of their lives. However, there is little theoretical clarity and cohesion with regard to the construct of future orientation or the processes involved in developing and shaping an individual's orientation toward the future.

In this connection, Arnett (2000), according to Galambos \& Martinez (2007) recognised that emerging adulthood may be restricted to industrialised nations which foster the luxury and freedom to explore multiple alternatives in life, but also maintained that globalization and economic advancement will lead to emerging adulthood in developing nations, whose characteristics may differ depending on the specific features of individual cultures. In the Africa sub region, the transition to adulthood is an arduous task characterised by several challenges (Lo-oh, 2009). Social and economic inequalities continue to mark a key challenge in Africa's child and youth life courses. While wealthier urban children and youth are beginning to experience problems with over nutrition, some rural youth still face nutritional deprivation (Nsamenang, 2007). Unemployment and crime rates are dramatically higher among rural youth and young adults. Wealthier youth and those in urban areas are more likely to be in school than their poor rural counterparts, and thus enjoy significant advantages in a labour market that increasingly rewards credentials and not basic skills (Lo-oh, 2009). The mark of rural poverty is clear in the elevated livelihood of rural youth participating in the labour force, in the high percentage of working youth employed in agriculture, and in the large-scale youth and young adult migration into urban settings (e.g. Ofosu-Kusi, 2014; Thorsen, 2014).

In the midst of all these, Africa's youth also suffer the effect of disease, especially HIV/AIDS and malaria, increasing rates of unemployment, alcoholism and drug trafficking, corruption and embezzlement, which continuously predict a bleak future for the future of African youth (Lo-oh, 2016). The outcome is that most young people's vision for adulthood is ill-fated by these difficulties with corresponding adverse effects on their conception of future life courses. Notably, in Cameroon, health care services, economic resources, and social services are unevenly distributed and many youth are left languishing in abject poverty, unemployment, under-resourced schools, and a difficult labour market economy (Lo-oh, 2012). School-to-work transitions are also a farce and it is increasingly difficult to manage the economics of adulthood and positive future orientation in becoming autonomous, financially independent, personally and socially responsible, emotionally stable and self-reliant (Lo-oh, 2009). With these difficult experiences, it is continuously difficult for young people to say exactly what they think their tomorrow will look like. Future orientation therefore, is highly contested between hopes and fears, however most at times clouded by fears of a bleak and unfulfilling future. That also explains why they usually proceed with life as though tomorrow will never come. And when asked what they think their futures will look like, their explanations are usually doubtful and contested against each other and with mixed feelings of hope and fear. Their future lives appear undefined and not mapped out so that everything is almost possible and impossible, with no clear direction of where they are going. This explains the double possibility of "becoming something... and becoming nothing..." dichotomy during this age.

\section{Literature review}

The conceptualization individuals develop regarding their future (e.g., their hopes, expectations, aspirations and fears) is an important factor for adolescents and young people because it strongly influences their identity formation, goal setting, decision-making process, and ultimately their behaviour (Lo-oh, 2016; Kerpelman \& Mosher, 2004; Seginer, Vermulst, \& Shoyer, 2004). Future orientation has been defined as one's mental representation of future life situations, shaped by personal and contextual influences (Nurmi, 1991). Other literature relate the construct to adult competence and attainment (Manzi, Vignoles \& Regalia, 2010), positive educational outcomes (Beal \& Crockett, 2010) and delinquency (Oyserman \& Markus, 1990). In the sociological literature, adolescent future orientation is seen as a predictor of adult attainment, for instance in education, work and career (Messersmith \& Schulenberg, 2008); and in the psychological literature, youth future orientation is used to predict behaviour and planning (e.g. Beal \& Crockett, 2010) and transitions to adulthood (e.g. Nurmi, 1994).

Future orientation therefore, is an ongoing multi-stage process in which an individual creates expectations for the future and sets goals and aspirations based on their values, experiences and environmental 
influences (Nurmi, 1991). In turn, these expectations then provide motivation for youth to engage in achievement behaviours that inadvertently lead them to productive future lives. But other future orientation research directs attention to fears of future life circumstances that must be dealt with or avoided on the one hand or fear of resources that must not be lost on the other hand. In line with this, Seginer (2009) drew from more than a century's research on potential or possible selves (e.g. Markus \& Wurf, 1986; Markus, Cross \& Wurf, 1990) to argue that there are three aspects of the self that inform notions of future orientation. These include the ideal self (what a person would like to become), the real self (what he/she could become) and the feared self (what one is afraid of becoming) commonly expressed in individuals' aspirations, hopes, goals and fears of future life.

Emerging adults and most young people consistently demonstrate a weaker orientation to the future than do fully grown adults. According to popular stereotypes in developmental literature, young people are notoriously short-sighted, oriented to the immediate rather than the future, unwilling or unable to plan ahead, and less capable than adults at envisioning the longer term consequences of their present decisions and actions (Steinberg, O’Brien, Cauffman, Graham, Woolard \& Banich, 2009). This myopia has been attributed to a variety of underlying conditions, among them, the lack of formal operational thinking (Greene, 1986), limitations in working memory (Cauffman, Steinberg, \& Piquero, 2005), and the fact that, relative to the amount of time they have been alive, an extension of time into the future is subjectively experienced by a youth as more distant than is the same amount of time to an adult (Gardner, 1993). Whatever the cause, youth short-sightedness has been implicated as a cause of the poor judgment and risky decision making so often evinced by young people, used as a rationale to place legal restrictions on the choices they are permitted to make, and suggested as one explanation for the general ineffectiveness of educational and developmental interventions designed to persuade them to avoid various health compromising behaviours, such as smoking, binge drinking, or unprotected sex (Steinberg, 2008).

Developmental psychologists interested in youth foresightedness and shortsightedness have generally studied it under the rubric of "future orientation." This term has been used to refer to a collection of loosely related affective, attitudinal, cognitive, and motivational constructs, including the ability to imagine one's future life circumstances (Nurmi, 1989), the length of time one is able to project one's imagined life into the future ("temporal extension"; Lessing,1972), the extent to which one thinks about or considers the future ("time perspective"; Cauffman \& Steinberg, 2000), the extent to which one is optimistic or pessimistic about the future (Seginer, 2009), the extent to which one believes there is a link between one's current decisions and one's future well-being (Somers \& Gizzi, 2001), the extent to which one believes he or she has control over his or her future (McCabe \& Barnett, 2000), and the extent to which one engages in goal setting or planning (Nurmi, 1991) for the future. These varied but potentially interrelated definitions indicate that future orientation, as it has been operationalized in developmental studies, has components that are cognitive, that is focused on the extent to which one thinks about the future; attitudinal, focusing on the extent to which one prefers long term, as opposed to short-term goals; and motivational with focus on the extent to which one formulates plans to achieve longterm goals (Nurmi, 2004). Although, as noted above, some researchers also have included an evaluative dimension of future orientation in their measures or models including the extent to which one is optimistic or pessimistic about the future (Trommsdorff, 1983), this strikes us as an entirely different phenomenon and one that is more likely linked to differences between individuals in their personalities and life circumstances (e.g., their degree of depression, their available resources) than to developmental factors.

That said, future orientation refers to an individual's tendency to engage in thinking about the future (Seginer, 2009) and involves expectations, hopes, and fears (Nurmi, 1991). It is also the ability to anticipate future events (McCabe \& Barnett, 2000). Research has shown that young people engage in thinking about the future and report future-oriented goals in a variety of life domains (Nurmi, 1991), including education and occupation (Seginer, 1988), social relationships (Carroll, 2002), and money and financial stability (Cohen \& Cohen, 2001). The relevance of future orientation for individuals' behaviours and developmental pathways has been postulated by psychologists and intuitively understood by lay persons (Seginer, 2009).

Primarily used by Lewin (1948) as "psychological future," Lewin, cited in Seginer (2009) argued that the picture presented by one's "psychological future," seldom corresponds to what actually happens later; but regardless of whether one's picture of the future is correct or incorrect at a given time, deeply affects the mood and action of the individual at that given time. And as a follow up on this, Seginer (2009) cited future metaphors commonly used in advertising and the business community to depict the power of the future and justify the relevance of future orientation to developing individuals. Among these, she cites: "Don't wait for the future, go find it," "Where there is care there is future," "You never really own a Pateck Phillipe (a Swiss made watch), you merely look after it for the next generation" and "The future isn't something you travel to, it's something you build up." Once formed and generated, Seginer (2009) maintained that possible selves perform three functions: motivational, evaluative and simulation. Specifically, future possible or potential selves act as incentives for future behaviour, provide individuals with an opportunity to evaluate the now selves in terms of their future 
aspirations, hopes and fears, and facilitate the materialization of future hopes and plans by allowing the individual imagine the action and resources needed to accomplish the task (Cross \& Markus, 1991).

Markus and Nurius (1986) theorized that people's imagined possible selves (i.e., the self an individual would like to be or is afraid of becoming) function as incentives and or disincentives for certain current behaviours through the projection of desired or undesired end-states. When individuals see themselves in a positive future state, they are less likely to form negative attitudes or engage in risky behaviours that will prevent them from achieving the desired end-state or lead to the undesired end-state (Oyserman \& Fryberg, 2006). By focusing on future plans, youth may avoid engaging in behaviours that could jeopardize their future selves. While research in the United States and other developed countries (Alm, 2011; Jacobs-Lawson \& Hershey, 2005) shows positive relationships between future orientation and behavioural outcomes, little is known about the influence of future orientation on youth and adult behaviours in developing countries, particularly in countries in Sub-Saharan Africa (SSA).

Most empirical studies investigate future orientation as a precursor of behaviour. Among youth, positive future orientation is related to academic achievement (Adelabu, 2007), and youth who are highly oriented toward the future - as measured by future planning - demonstrate lower incidences of misconduct (Chen \& Vazsonyi, 2013), higher rates of intention to use condoms (Bryan, Kagee, \& Broaddus, 2006), and higher perceived academic self-efficacy (Kerpelman, Eryigit, \& Stephens, 2008). Youth with higher levels of future orientation also are less likely to engage in drug and alcohol abuse, unsafe sexual practices (Somers \& Gizzi, 2001), and violent behaviours over time (Stoddard, Zimmerman, \& Bauermeister, 2011). Future orientation also can mitigate the effects of traumatic events and the stigma of depression and other mental health issues (Wang, Li, Barnett, Zhao, \& Stanton, 2012; Zhang, Zhao, Li, Hong, Fang, Barnett \& Zhang, 2009). For adults, higher future orientation also is associated with lower suicidal ideation and suicide attempts (Hirsch, Duberstein, Conner, Heisel, Beckman, Franus \& Conwell, 2006) and improved health through regular exercise (Kahana, Kahana, \& Zhang, 2005). In addition to positive health and educational outcomes, higher levels of future orientation are associated with desirable financial and economic outcomes that include saving among youth (Webley\&Nyhus, 2006) and work motivation (Seijts, 1998), pursuit of higher education (Peetsma, 2000), and retirement planning (Jacobs-Lawson \& Hershey, 2005) among adults. Conversely, indifference toward the future results in lower educational attainment, greater risk of experiencing economic hardships (Alm, 2011), and aggression (Bushman, Giancola, Parrott, \& Roth, 2012).

Some studies show that future orientation is influenced mainly by psychological or personality traits such as conscientiousness and emotional stability (Hershey \& Mowen, 2000), social norms regarding the perception of time (Jones, 1988), and perceived proximity to death (Carstensen, 2006). Fewer investigations examine the potential influence of economic resources such as asset ownership on future orientation. From theoretical and applied perspectives, examining the extent to which economic resources impact the future orientation of parents and their children may help researchers and policymakers understand the effects of interventions and programs aimed at increasing income, consumption and asset ownership. Positive future orientation that could result from improved economic circumstances may lead to other desirable outcomes such as improved health conditions, higher educational attainment, and financial stability. Examining the relationship between economic resources and future orientation also may help us understand external variables-particularly economic resources - that shape personality development.

The primary models or theories of future orientation across domains include possible selves theory (Markus \& Nurius, 1986), hopes and fears (Nurmi, 1989), future time perspective (Trommsdorff, 1983; Lens and Moreas, 1994), aspirations and expectations (Gottfredson, 1981; Messersmith \& Schulenberg, 2008) and hope theory (Snyder, 2002). Possible selves are defined as "positive and negative images of the self already in a future state" (Oyserman \& Fryberg, 2006). Nurmi (1989) offered a more comprehensive definition of future orientation, which he conceptualized as a multidimensional process of motivation, planning, and evaluation, where motivation is what interests an individual has, planning is how an individual intends to realize a particular future goal, and evaluation is the extent to which realizing a goal is expected by that individual. The contrast between these two definitions is clear: for possible selves, future orientation is the affect (i.e., positive/negative) and content of a future state, whereas for hopes and fears the plans to achieve and belief about success in achieving a future state are also part of future orientation (Nurmi, 1989).

With regard to aspirations and expectations, Gottfredson (1981), who focused on occupational aspirations and expectations, conceptualized aspirations as the range of possible goals being considered at any given time, and the expectation as the single goal identified as the best alternative at any given time. Once again, this conceptualization, when posed in contrast with the previous two definitions described, provides another aspect of future orientation to consider: not only the content and the perceived likelihood of success, which were elements of the other two definitions, but also the consideration of multiple cognitions and comparison of cognitions based on the individual's current experiences/knowledge. Meanwhile, Trommsdorff (1983) offered a definition of future orientation that encompasses all of the components described with some additions. She 
suggested that future orientation encompasses the length of extension into the future, domain or content of the cognition, number of cognitions, amount of detail, affect tied to the cognition, motivation to achieve the cognition, and the amount of control an individual believes he or she holds over goal attainment. Finally Snyder's (2002) hope theory identified three key indicators: goal setting, pathway and agency as important elements of future orientation. The theory highlights the importance of setting goals for what the individuals wants to do or become in their future life; finding different pathways or ways by which to attain the goals; and believing they can initiate action and change their lives towards desired futures. Particularly informed by the hopes and fears perspective, this study integrated elements of possible selves, future time perspective, aspirations and expectations and hopes to investigate into the phenomenon of future orientation among emerging adults in Cameroon. It particularly examined their hopes and fears, and the corresponding implications for dependable and productive adult futures.

\section{Methods \\ 3.1 Participants}

The sample of the study was 137 emerging adult university students, aged 18-26 and selected from two state universities in Cameroon. Out of the 137 participants, there were $103(75.2 \%)$ females and $34(24.8 \%)$ males. Majority of the participants was age 21-23 (40.1\%), followed by 24-26 (35\%), meanwhile, only $7(5.1 \%)$ were in the youngest range 18-20. Majority of the participants, $83(80.6 \%)$ was selected among the Western grass fields of Cameroon; meanwhile $48(35 \%)$ was selected among the Coastal Tropical Forest Peoples of Cameroon. Majority of participating students, $85(63.9 \%)$, were third or final year university students and were closely followed by $33(24.08 \%)$ fourth year university students. First and second year university students were only 8 $(5.8 \%)$ and $11(8 \%)$ of the sample respectively. In terms of marital status, majority of the sample, $115(83.9 \%)$ reported they were never married, $16(11.7 \%)$ were married and were currently in their first marriage, $4(2.9 \%)$ were co-habiting while $2(1.5 \%)$ were already divorced. The bulk of the sample was recruited from elitist family backgrounds, with parents, most of whom had at least gone through secondary school education.

\subsection{Procedure}

This research was part of a larger study that was aimed at investigating developmental trends, strategies and challenges that stand in the way to adulthood for emerging adults in Cameroon. While in the selected universities and taking cognizance of age, university students were conveniently and systematically selected for the study. The use of conveniently and systematically selected participants required the researcher to have access to particular types of participants who were especially likely to help in gaining an understanding of the phenomenon of thinking about the future of adulthood. Therefore, to ensure credibility and reliability of the quality of the sample, participants were first sorted demographically (in terms age), then further given the opportunity to understand the research idea, and finally, they wilfully enlisted themselves as participants in the study. A brief discussion was conducted with volunteered participants to establish if they were actually conversant with the phenomenon of thinking and reflecting about the future of their adulthood; future orientations, their resources or careers to adulthood as well as their hopes and fears in their future orientation. At the end of the discussion with volunteered participants, and based on the researcher's discretion, 137 students were recruited into the study.

The Hopes and Fears questionnaire (Seginer, 2009) was used to collect data on emerging adult future orientations depicting hopes and fears. Two open-ended items on self-perceived hopes and fears for the future as well as options on the way to adulthood were constructed to provide data on self-perceived hopes and fears in the pathway to adulthood. Data collected was analyzed descriptively according to content categories or life domains including future orientations towards education, work and career, marriage and family, self-concerns, others and collective issues (Seginer, 2009). The essence was to determine emerging adult hopes and fears towards these life domains. Frequency counts of mentions of a particular life domain as well as the particular hopes or fears attached to such categories were done and presented descriptively to determine the most popular future orientation life domain as well as typical hopes and fears. Open-ended items on self-perceived options in the pathway to adulthood were also coded into various themes or categories.

\section{Findings}

The study set out to describe emerging adult visions of their future of adulthood. Findings showed that young people's visions for adulthood were pitted against hopes and fears. In other words, on one hand, they looked up to the future with hope that it would be a productive and life-fulfilling age-bracket and on the other hand, they looked up to the future of adulthood with a lot of fear that it would not be as productive and life-fulfilling as 
wished. However on the overall, more than $70 \%$ of young people sampled felt more hopeful, but their pessimistic visions of adulthood were more developed and expansive than optimistic futures.

Table 1. Hopes for productive adult futures

\begin{tabular}{|l|cc|}
\multicolumn{1}{c|}{ Perceived hopes } & Frequency & Percentage \\
\hline Work and career & 104 & 75.9 \\
Marriage and family & 77 & 56.2 \\
Education & 53 & 38.7 \\
Others & 52 & 38 \\
Self-concerns & 43 & 31.4 \\
Collective issues & 25 & 18.2
\end{tabular}

On hopes for productive futures of adulthood, $75.9 \%$ hoped for a productive and fulfilling future of work and career implying that whatever they did now was in preparation for work and career building. Meanwhile 56.2\% looked up to marriage and family as indicators for a productive adult life for them and strategies highly cited included responsible dating relationships, intimate relationships and cohabitation. Another $38.7 \%$ felt that their productive futures depended on education with strategies for continuing education in order to obtain higher degrees in higher education and training (58\%). Here $19.7 \%$ of them also pointed to school success and academic achievement as a good strategy towards a hopeful future. Other young people, $38 \%$ of them focused on others in order to build productive futures for themselves. In other words, to succeed and become as productive as wished in the future, they felt that significant others in their lives were very important. Therefore, building dependable and productive networks, social support systems, friendships and peer support networks stood out as key resources for hopeful futures. Whereas some young people hoped for supportive "others" to succeed in the future, others $(31 \%)$ felt that productive adult futures were dependent on self-related variables. Here they made particular reference to hard work and motivation (58\%), resilience (31\%), personal agency and effort (31\%), staying focused and steadfast $(36.5 \%)$ adaptation to one's life circumstances $(19.7 \%)$ and health and wellness $(20 \%)$. Finally, $18 \%$ considered the future of their adulthood as dependent on collective variables such as community support programmes $(21.9 \%)$ and supportive relationships and connections (26\%).

Table 2. Fears towards productive adult futures

\begin{tabular}{l|cc|} 
Perceived fears & Frequency & Percentage \\
\hline Insufficient finances & 92 & 67.2 \\
Unemployment & 72 & 52.6 \\
Individual/Personality related difficulties & 66 & 48.2 \\
Insufficient support programs & 63 & 46 \\
Relationship, marriage and family life problems & 55 & 40.1 \\
Family influence/pressure & 47 & 34.3 \\
Peer pressure and school failure & 41 & 29.9 \\
Disease and death & 41 & 29.9 \\
Insufficient educational opportunities & 41 & 29.9 \\
Country's economic crisis and corrupt practices & 37 & 27 \\
Witchcraft and untimely death & 36 & 26.3
\end{tabular}

Of the most prevalent fears on the road to productive adult futures were fears of economic downsides and hardships marked by insufficient funding (67\%) which for them could only be overcome by the provision of work and employment opportunities $(70.8 \%)$ and work and education (45\%). Closely related to insufficient funding was the very high prevalent fear of unemployment $(52.6 \%)$ during the transition to productive adult futures. This was consistent with the very high rate of youth unemployment in Cameroon, as high as $70 \%$ among young people. Individual and personality-related difficulties $(48.2 \%)$ were also considered to be among the fears for a future of productive adulthood for emerging adults; and closely related to this were fears of insufficient support programmes (46\%) to accompany young people in the transition to adulthood. Forty percent (40\%) of emerging adults feared for failing relationships, marriages and family life problems in their future lives and felt that they needed supportive relationships and connections, successful marriages and family wellbeing to have productive and life-fulfilling adulthoods. Some of their fears on the road to productive adulthood were linked to issues of family pressure $(34.3 \%)$; and peer pressure and school failure (29.9\%). In this wise, emerging adults feared their dreams may be deviated in some way by family-related and peer group-related influences and demands so that they would not get to their desired adult futures. Some of them, especially those who thought 
that education and schooling were better trajectories for productive adulthood feared for failed grades at school and held that with such school failure, their futures may be doomed. Closely related to the issue of school failure was the fear of insufficient educational opportunities $(29.9 \%)$ to accompany young people towards productive adulthood. Another group of emerging adults linked their fears on the road to productive adulthood to a number of societal ills among others, the country's economic crisis and corrupt practices (27\%) as well as witchcraft and untimely death $(26.3 \%)$

\section{Table 3. Perceived options on the road to productive adulthood}

Perceived options

Education, work and marriage

Work and employment

Continuing education

Continuing education and marriage

Marriage/family formation

Work and education

Child bearing and parenthood
Frequency Percentage

$\begin{array}{cc}117 & 85.4 \\ 97 & 70.8 \\ 80 & 58.3 \\ 78 & 56.9 \\ 70 & 51.1 \\ 63 & 45.9 \\ 60 & 43.8\end{array}$

Given the notions of possible and potential future selves as well as the hopes and fears held by emerging adults, we sought to determine the perceived options or pathways emerging adults felt could take them to their desired futures or help them escape or avoid their feared futures. A significant proportion of them, $85.4 \%$ felt that education, work and marriage were dependable pathways that could be adopted in the transition to dependable and productive adult futures. In more specific terms, $70.8 \%$ of them preferred going to adulthood through work and employment while $58.3 \%$ opted for continuing education and $56.9 \%$ thought that both continuing education and marriage were indispensable pathways to productive adult futures. Finally, $51.1 \%$ of emerging adults thought that marriage and family formation were important variables in the pathway to adulthood, while work and education $(45.9 \%)$ and child bearing and parenthood $(43.8 \%)$ were equally held as dependable options on the road to productive adult futures in Cameroon.

\section{Discussions}

\subsection{Self-perceived hopes for productive adult futures}

The most important hopeful themes for the future of productive adulthood recorded in this study were futures of work and career, marriage and family, education, significant others, personal efforts as well as collective issues. In other words, emerging adults in Cameroon still hold strongly to the socially constructed and institutionalised standards of becoming adult: finishing school, finding full-time work and employment, exit from parental residential space, getting married and parenthood. Variously, these were consistent with Johnson (1987) who found youth with expectations to be married with children, to own a home and a car, to be richer than their parents, and happier than they are now. While in their own studies (Hicks, 1996) and Nurmi (1991) found that young people often and very often think about their futures; and when they did so, their main hopes pointed to a future of education, work, relationships, and achieving a good life. In his life course theory of future orientation, Nurmi (1989) maintained that young people often hold future-oriented cognitions regarding anticipated tasks that they must complete during adulthood. Later he would refer to three life domains including normative and socially constructed life-tasks such as getting good education and employment; non-normative events relating to their parents and family, such as health and divorce; and societal historical events, such as threat of war and insecurity (Nurmi, 1991). These tasks would require consideration and planning for educational goals, possible occupations, relationships and intrapersonal characteristics. In relation to future life domains, Seginer (2009) identified eight major domains of future orientation among young Israelites: school and graduation, military service, higher education, work and career, marriage and family, self-concerns, others and collective issues. Similar to the present findings, Seginer (2009) in each of the future life domains found emerging themes that suggested hopes and fears related to the different domains. Among other hopes for instance, as far as school and graduation is concerned, young people hoped to complete their high school and college requirements in the future, move to a better school and some even made references to scoring better grades in some subjects. This is also related to Young Lives (2016) which argued that even though many parents of today's children and youth did not go to school or had only minimal education, they and their children see education as priority-and a route to a better life. On work and career, specific hopes for the future touched on entering a specific career, and above all a job that will earn them money and a high social position in their society. Behrman \& Sengupta (2006) had argued that economic stagnation and poverty inevitably limit opportunities for youth as they make the transition 
to adulthood. Some hoped not only to marry but to marry their current partners (showing the importance ascribed to dating), hoped for an understanding spouse and wonderful children as well as a big family. A fundamental domain of future orientation is self-concern and like Seginer (2009), we found that among other considerations in this domain, young people hoped to be happy, to be loved by others, to be respectable in their community and society, to be honest, to be courageous, to be good, and that all their hopes and wishes will be fulfilled. In their own study Johnson, Blum \& Cheng (2014) defined hopeful futures from the perspective of possible selves, career prospects and beliefs in their futures. Based on these, they argued that possible selves often motivate behaviour; and in particular, they found that more academic possible selves influence youth self-regulatory behaviours including improved academic practices (i.e., homework and initiative) and reduced disruptive behaviour in class and in school. The implication is that hopes for academic related achievements in the future ought to be accompanied by appropriate plans and behaviours that could enable their success. On career prospects in the future they found two commonly studied constructs including vocational identity and career maturity, in which case they most likely hoped for a particular job or hoped to mature in their career. Vocational identity refers to the clarity of adolescents' pictures of their goals, interests, and talents (Holland, Daiger \& Power, 1980). It is acquired through a process of career exploration meanwhile career maturity measures the success of career exploration. That is why career maturity has been viewed as the extent to which an individual has acquired the necessary knowledge and skills to make intelligent, realistic career choices (Levinson, Ohler, Caswell, \& Kiewra, 1998).

\subsection{Self-perceived fears towards productive adult futures}

Despite significant economic growth rate reports in many African countries and the rest of the developing economies today, significant economic and social inequalities persist. Young Lives (2016) maintains that children and youth from poor families, rural areas and from ethnic minority families continue to fare much worse than their peers. Those from rural areas and from socially disadvantaged groups continue to have less access to clean water and sanitation than their better-off peers. These persistent inequalities, no doubt have exacerbated fears for futures of productive lives. This is also true when we consider the reality of today's more demanding labour markets, increasing job insecurity, reduced job and training opportunities, and high rates of unemployment (Lo-oh, 2012). In this regard, Behrman \& Sengupta (2006) argued that economic stagnation and poverty inevitably limit opportunities for youth as they transition to adulthood. And Smith, Christofferson, Davison \& Herzog (2011) argued that even though emerging adults have the freedom to shape their future lives, they are usually fully dependent of their parents, because they may lack stable social and economic status. It is even more compelling for emerging adults in Africa and other under-developed societies who experience high risks, with low levels of competencies and lower prospects for higher education training to empower their skills and ensure hope for successful entry into adulthood (Lo-oh, 2016).

Besides these, young people have been characterised as notoriously shortsighted, oriented to the immediate rather than the future, unwilling or unable to plan ahead, and less capable than adults at envisioning the longer term consequences of their decisions and actions (Steinberg, O’Brien, Cauffman, Graham, Woolard \& Banich, 2009). Like in Cameroon and perhaps, elsewhere in the developing world, Brown, Teufel, Birch \& Kancherla (2006) maintained that fearful and worrisome images of the future have become common in the United States and adolescents are increasingly bombarded with messages regarding their safety and security. In fact, worry or fear in adolescence is a phenomenon that emphasizes negative outcomes and uncertainty about future events (Laugesen, Dugas \& Bukwoski, 2003). Regrettably, such fears and worries have been associated with important behavioural and health outcomes, including insomnia, poor social skills and weak academic skills, putting young people at greater risk of school failure and dropout (Brown et al, 2006). We have discussed these findings in a way that develops not only the hopes and fears towards productive adult futures but also the options and strategies young people identified as important on the road to productive adult futures.

The most important themes of fear for the future of productive adulthood recorded in this study were fears related to work and career, marriage and family, education, significant others, personal efforts as well as collective issues. In specific terms, they feared for a future of unemployment and insufficient financial standing to enable them manage their adult status and be productive; some fears were linked to personality related difficulties and insufficient support programs, not only to help young people manage their individual difficulties but also propel them through adulthood. Some others' fears were linked to relationship, marriage and family life related problems such as "no marriage at all," "break up and divorce" as well as problems raising their children. Finally some feared for disease and death, no educational opportunities, the country's economic crisis and corrupt practices as well as witchcraft and untimely death, an observed phenomenon, very common in many traditional African societies.

Seginer (2009) found similar findings among young people in Israel. In the domain of education as a transition mechanism, young people feared failing their exam or getting admitted into their dream programmes of study; some feared they will not have enough money to continue their education; and their parents will not 
allow them study in a university away from home. In the area of work and career, they feared not becoming the professional they wish themselves, becoming unemployed and not accepted to work by the family. When Seginer (2009) considered marriage and family, participants feared being childless, not marrying the right person, being treated harshly by their spouse and feared that something bad will happen to their children. On self-concerns, the young Israelites feared to have an unhappy life in the future, not becoming the happy and respectable person they wish themselves and also feared for disappointments in life. Among others, fears towards others included fears of terrible things happening to their parents and siblings. In relation to the present study, and with consideration for others, they particularly feared losing their parents, and particularly their sponsors.

Like in previous studies (e.g. Liauw, 2013 \& Nurmi, 2005), the present study found that evaluative feelings and attitudes of the affective dimension of future orientation not only included hope and optimism but also fear, pessimism and worry about the future. Among others, respondents worried and feared for insufficient finances with which to manage their uncertain futures, unemployment, personality-related problems, relationship, marriage and family life problems, disease and death as well as insufficient educational opportunities. These were consistent with Laugesen, Dugas \& Bukowski (2003) who found that worry and fear in adolescence is characterised by negative outcomes and uncertainty about future events. And Liauw (2013) also maintained that such fears for an uncertain future are associated with important behavioural and health outcomes including insomnia, poor social skills and weak academic skills, putting the individual at greater risk of school failure or dropout.

\subsection{Self-perceived options on the road to positive and productive adult futures}

Like in previous studies where the transition to adulthood is socially constructed and institutionalised (e.g. Richter \& Panday, 2006; Arnett, 1997; Hogan \& Astone, 1986; Kohli \& Meyer, 1986), findings on perceived options and trajectories towards adulthood pointed to pathways, in the most part, through education, work and marriage as dependable routes to productive adult futures. This is consistent because for many decades, scholars held that entry into adulthood was delineated by five transition markers: completing school, leaving home, beginning one's career, marrying, and becoming a parent (Shanahan 2000; Settersten, 2006). In line with these, Kohli \& Meyer (1986) argued that institutionalizing the life course, or better still, the transition to adulthood, through education and other social institutions such work, marriage and parenthood shaped and guided the expectations according to which individuals plan their futures. In particular, Hogan \& Astone (1986) referred to the importance of role transitions such as finishing education, entering the labour force, marriage and parenthood, thereby confirming the pattern that is most exemplified in the sociological literature and in most under-developed societies. In this respect, social definitions of what it means to be an adult, for oneself or for others, have evolved in response to the changes in emerging adulthood (Furstenberg, Kennedy, McCloyd, Rumbaut, \& Settersten, 2003). For example, young people today are entering adolescence earlier and healthier than before; more likely to spend their adolescence in school; more likely to postpone entry into the labour force; and more likely to delay marriage and childbearing (LIoyd, 2005)). And Lo-oh (2012) found evidence in Cameroon that education has extended into the late twenties and early thirties sometimes even more; family formation has been postponed right up to the thirties and beyond; and many young people more than ever before plan on remaining single and childless well into their thirties, if not indefinitely.

Still within the realm of generational shifts affecting the transition to adulthood, studies have shown that a higher proportion of students completed high school in the 1990s than in the 1960s, and more students now enroll into university education, pushing forth the age of leaving school; and the median age for marriage and first birth has risen steadily since the 1970s so that it has become more common to have a child before marrying or to re-enter school after spending sometime in the labour force (Lo-oh, 2012). In line with these, Richter \& Panday (2006) found that young South Africans like other African youth spend more time in school today and experience delayed entry into the labour force, having to contend with inordinately high rates of unemployment where leaving school does not lead to a job, therefore delaying the work option. Marriage is also delayed by the longer time spent in school; delays in finding employment; and prolonged economic and residential independence (Lo-oh, 2009, 2012). It therefore seems going to adulthood today is not only prolonged and destandardized but also uncertain and reversible since young people have to manage shifts between dependency and independence and back to dependence, either through personal choice or forced by delays in education, unemployment, relationship breakdown and the many other challenges standing on the way to adulthood (Stauber \& Walther, 2002). In this connection, Lo-oh $(2012,2017)$ argued that in Africa, young people's vision for adulthood is ill-fated by difficult economic, social, political, cultural, health and psychological conditions that have left them hopeless and fearful about their futures. In most African countries, health care services, economic resources, and social services are unevenly distributed and as a result majority of youth are left languishing in abject poverty, unemployment, under-sholarisation, and a difficult labour market economy (Lo-oh, 2012) which 
of course increasingly makes it difficult to manage the economics of adulthood and attain autonomy, financial independence, personal and social responsibility, emotional stability and self-reliance.

The institutionalization of the pathway to adulthood is also guided by Africentric conceptions of child and youth development practices, customs and traditions as well as child rearing practices. Such conceptions give value to role transitions so that it is no doubt when young people consider socially constructed standards as key trajectories to adulthood. According to Araria (2007) and Nsamenang (2002) Africans conceive of the adolescent as growing out of childhood and poised for an adulthood that lies in the future And in African social ontogeny, adolescence is regarded as a "way station" between the stages of social apprenticeship in childhood and full social integration in adulthood beginning with social entrée, characterised by learning to perform domestic chores and participating in rites of passage; and probation and socialized internship towards social institutions or roles typical in adulthood (Nsamenang, 2002, 2016; Serpell, 1994). Some scarce African developmental literature has used garden metaphors such as "buds of hope and expectation" (Zimba, 2002), gradually "becoming" (Erny, 1987) and socialized agents of their culture (Nsamenang, 2007) to refer to young people in transition. By so doing, a lot of investment is made to accompany young people through dependable routes to productive adult futures. That is why in most African customs and traditions, the transition period would be typically marked by rituals, rites of passage, and initiations into diverse sacred societies and adult standards to signal the individual's coming of age. By going through these rituals and assuming adult roles, youth are thought to relinquish the hallmarks of adolescence, including dependency on parents, immature behaviour that reflects experimentation with roles, and indecision about one's identity; and in turn, the rituals or rites of passage and the newly acquired adult roles bring with them strong expectations for productive adult futures (Shanahan, Porfeli, \& Motimer, 2005).

\subsection{Conclusions}

Youth expectations of the future are important vectors for adult futures since they serve as powerful motivators of current decisions, way of life and choices (Nurmi, 1991). Moreover, the kinds of expectations that adolescents and emerging adults hold for their futures have been linked to psychosocial outcomes, positive and productive adulthood and successful attainment of event markers of adulthood (McCabe \& Barnett, 2000). There is also evidence that gaining an understanding of how young people see their futures could provide insight into their long-term development (Raffaelli \& Koller, 2005) with significant insights on future orientation (Seginer, 2009). According to Nsamenang (2007) discourse on Africa's youth has not transcended the rhetoric of "calamity" that visualises, casts and intervenes the young as problematic cohorts in the tedium of global imperatives offered to humanity by western civilization. That is why they have often remained "silent others", the voiceless enfants terribles (Caputo 1995; Gottlieb 2000) and the incompetent category, blinded, confused and without a focused sense of vision (Lo-oh, 2017). They are often constructed from the outside and from above as a "problem" or a "lost generation" (Cruise O’Brien 1996) living a life in "crisis" (Everatt and Sisulu, 1992). Most recently, they have been defined as a "black box", a "generation x" or the uncertain and doubtful "twenty somethings" (e.g. Arnett, 2004). There is little understanding and doubtful data on the circumstances and imagined futures of Africa's huge next generations in their own experiences and voices.

While this study has delved into the subject of future expectations of Cameroonian young people, addressing their hopes and fears as they transition to adulthood, it has also had cause to examine the perceived options, routes and dependable pathways to productive adult futures. This in part to not only contribute to the future orientation research paradigm but also understand the hopes and fears that are characteristic of these youth collected in their own voices. This study showed that the tendency to think about the future is well developed among emerging adults in Cameroon; and like in most of the literature, their images of the future are often caught between hopes and fears (e.g. Seginer \& Halabi-Kheir, 1998). According to them, future orientation constitutes an important developmental task during which emerging adults have to consider, plan and prepare for the future. Again future identities in this study were quite diverse in terms of hope for continuing education, engaging in marriage and family formation, work and career development, and so on. Consistent with (Lo-oh, 2016; Nurmi, 1991), while they created multiple identities in these life domains, they also expressed significant fears in not continuing their education, loosing sponsorship, becoming poor, becoming unemployed, not getting married and having children of their own and so on. Compared against hope and optimistic futures, however, findings showed that pessimistic visions or fears of the future of adulthood were more developed and expansive than optimistic futures where emerging adults were more skeptical about their futures. On road options towards the future of adulthood, significant pointers were education, work, marriage and parenthood. In fact, a lot of young people identified with the socially constructed and institutionalised standards of becoming adult: finishing school, finding full-time work and employment, leaving home, getting married and parenthood. 


\section{References}

Adelabu, D. H. (2007). Time perspective and school membership as correlates to academic achievements among African American adolescents. Adolescence, 42(167), 525-538.

Alm, S. (2011). The worried, the competitive and the indifferent-Approaches to the future in youth, their structural roots and outcomes in adult life. Futures, 43(5), 552-562.

Araia, B.B. (2007). Eritrea. In Jeffrey Jensen Arnett (Ed.) (2007). International encyclopedia of adolescence. New York: Routledge.

Arnett, J.J. (2004). Adolescence in the twenty-first century: A worldwide survey. In U.P. Gielen \& J.Roopnarine (Eds.), Childhood and adolescence: Cross-cultural perspectives and applications. Westport, CT: Praeger.

Arnett, J.J. (2000). High hopes in a grim world: Emerging adults' views of their futures and Generation X. Youth \& Society, 31(3), 267-286.

Arnett, J.J. (1997). Young people's conceptions of the transition to adulthood. Youth \& Society, 29(1), 3-21.

Beal, S.J. (2011). The development of future orientation: Underpinnings and related constructs. Theses, dissertations and student research. Lincoln: University of Nebraska.

Beal, S.J. \& Crockett, L.J. (2010). Adolescents' occupational and educational aspirations and expectations: Links to high school activities and adult educational attainment. Developmental Psychology, 46(1), 258-265.

Becker, B., \& Luther, S. (2002). Social-emotional factors affecting achievement outcomesamong disadvantaged students: Closing the achievement gap. Educational Psychologist, 37, 197-214.

Behrman, J. R., \& Sengupta, P. (2006). Changing contexts in which youth are transitioning to adulthood in developing countries: Converging toward developed economies? In C. B. Lloyd, J. R. Behrman, N. P. Stromquist, \& B. Cohen (Eds.), The changing transitions to adulthood in developing countries: Selected studies (pp. 13-55). Washington, DC: National Academies Press.

Broomfield, K.A. (2007). Mechanisms through which supportive adult relationships and future orientation contribute to positive outcomes in low-income African American adolescents. Psychology Dissertations. Paper 33.

Brown, S.L., Teufel, J.A., Birch, D.A. \& Kancherla, V. (2006). Gender, age and behaviour differences in early adolescent worry. Journal of School Health, 76(8), 430-437.

Bryan, A., Kagee, A., \& Broaddus, M. R. (2006). Condom use among South African adolescents: Developing and testing theoretical models of intentions and behaviour. AIDS and Behaviour, 10(4), 387-397.

Bushman, B. J., Giancola, P. R., Parrott, D. J., \& Roth, R. M. (2012). Failure to consider future consequences increases the effects of alcohol on aggression. Journal of Experimental Social Psychology, 48(2), 591595.

Call, K., Reidel, A., Hein, K., McLoyd, V., Petersen, A. \& Kipke, M. (2002). Adolescent health and wellbeing in the twenty-first century: A global perspective. Journal of Research on Adolescence, 12(1), 69-98.

Caputo, V. (1995). Anthropology's silent others: A consideration of some conceptual and methodological issues for the study of youth and children's cultures. In V. Amit-Talai \& H. Wulff (Eds.), Youth cultures: A cross-cultural perspective. London: Routledge

Carroll, A. (2002). At-risk and not at-risk adolescent girls in single-sex and mixed-sex school settings: An examination of their goals and reputations. Westminster Studies in Education, 25, 147-162.

Carstensen, L. L. (2006). The influence of a sense of time on human development. Science, 312, 1913-1915. 
Cauffman, E., Steinberg, L., \& Piquero, A. (2005). Psychological, neuropsychological, and psychophysiological correlates of serious antisocial behaviour in adolescence: The role of self-control. Criminology, 43, $133-176$.

Cauffman, E., \& Steinberg, L. (2000). (Im)maturity of judgment in adolescence: Why adolescents may be less culpable than adults. Behavioral Sciences and the Law, 18, 741-760.

Chen, P., \& Vazsonyi, A. T. (2013). Future orientation, school contexts, and problem behaviours: A multilevel study. Journal of Youth and Adolescence, 42, 67-81.

Cohen, P., \& Cohen, J. (2001). Life values and mental health in adolescence. In P. Schmuck \& K. M. Sheldon (Eds.), Life goals and well-being: Toward a positive psychology of human striving. Gottingen: Hogrefe and Huber Publishers.

Cross, S., \& Markus, H. (1991). Possible selves across the life span. Human Development, 34(4), 230-255.

Cruise O’Brien, D. (1995). A lost generation? Youth identity and state decay in West Africa. In R. Werbner \& T. Ranger (Eds.), Postcolonial identities in Africa. London: Zed Books.

Erny, P. (1987). L'enfant et son milieu en Afrique noire (The child and his environment in black Africa). Paris: L'Harmattan.

Everatt, D. \& Sisulu, E. (1992). Black Youth in Crisis Facing the Future. Johannesburg: Ravan Press.

Furstenberg, F.F., Kennedy, S., McCloyd, V.C., Rumbaut, R.G., \& Settersten, R.A., (2003). Between adolescence and adulthood: Expectations about the timing of adulthood. In R. Al, Jr. Settersten, F.F. Furstenberg, Jr., and R.G. Rumbaut (Eds.). On the frontier of adulthood: Theory, research and public policy. Chicago: University of Chicago Press.

Galambos, N.L. \& Martinez, M.L. (2007). Poised for emerging adulthood in Latin America: A pleasure for the privileged. Child Development Perspectives, 1(2), 109-114.

Garcia, M. \& Fares, J. (2008). Youth in Africa's labour market. Washington, DC: The World Bank.

Gardner, W. (1993). A life-span rational choice theory of risk taking. In N. Bell \& R. Bell (Eds.), Adolescent risk taking. Newbury Park, CA: Sage.

Gottfredson, L.S. (1981). Circumscription and compromise: A developmental theory of occupational aspirations. Journal of Counselling Psychology, 28(6), 545-579.

Gottlieb, A. (2000). Where have all the babies gone? Towards an anthropology of infants and their caretakers. Anthropology Quarterly, 73(3), 121-132.

Greene, A. (1986). Future time perspective in adolescence: The present of things future revisited. Journal of Youth and Adolescence, 15, 99 - 113.

Hershey, D. A., \& Mowen, J. C. (2000). Psychological determinants of financial preparedness for retirement. The Gerontologist, 40(6), 687-697.

Hicks, D. (1996). A lesson for the future: Young people's hopes and fears for tomorrow. Futures, 28(1), 1-13.

Hirsch, J. K., Duberstein, P. R., Conner, K. R., Heisel, M. J., Beckman, A., Franus, N., \& Conwell, Y. (2006). Future orientation and suicide ideation and attempts in depressed adults ages 50 and over. American Journal of Geriatric Psychiatry, 14(9), 752-757.

Hogan, D.P. \& Astone, N.M. (1986). The transition to adulthood. American Sociological Review, 12, 109-130. 
Holland, J.L., Daiger, D.C., \&Power, P.G. (1980).My Vocational Situation: Description of an experimental form for the selection of vocational assistance. Palo Alto, CA: Consulting Psychologists Press.

Jacobs-Lawson, J. M., \& Hershey, D. A. (2005). Influence of future time perspective, financial knowledge, and financial risk tolerance on retirement saving behaviours. Financial Services Review, 14(4), 331-344.

Johnson, S.L., Blum, R.W. \& Cheng, T.L. (2014). Future orientation: A construct with implications for adolescent health and wellbeing. International Journal of Adolescent Health, 26(4), 459-468.

Jones, J. M. (1988). Cultural differences in temporal perspectives: Instrumental and expressive behaviours in time. In J. E. McGrath (Ed.), The social psychology of time: New perspectives. Newbury, CA: Sage.

Kahana, E., Kahana, B., \& Zhang, J. (2005). Motivational antecedents of preventive proactivity in late life: Linking future orientation and exercise. Motivation and Emotion, 29(4), 438-459.

Kerpelman, J. L., Eryigit, S., \& Stephens, C. J. (2008). African American adolescents' future education orientation: Associations with self-efficacy, ethnic identity, and perceived parental support. Journal of Youth and Adolescence, 37(8), 997-1008.

Kerpelman, J.L., \& Mosher, L.S. (2004). Rural African-American adolescents' future orientation: the importance of self-efficacy, control and responsibility, and identity development. Identity: An International Journal of Theory and Research, 2, 187-208.

Kohli, M. \& Meyer, J.W. (1986). Social structures and social construction of the life stages. Human Development, 29, 145-149.

Laugesen, N., Dugas, M.J., \& Bukowski, W.N. (2003). Understanding adolescent worry: The implication of a cognitive model. Journal of Abnormal Child Psychology, 31(1), 55-64.

Lens, W., \& Moreas, M. (1994). Future time perspective: An individual and a societal approach. In Z. Zaleski (Ed.), Psychology of Future Orientation. Lublin, Poland: Kul.

Lessing, E. (1972). Extension of personal future time perspective, age and life satisfaction of children and adolescents. Developmental Psychology, 6, 457 - 468

Levinson, E.M., Ohler, D.L., Caswell, S., \&Kiewra, K. (1998). Six approaches to the assessment of career maturity. J CounsDev, 76(4), 475-482.

Liauw, I. (2013). Examining trends in adolescents' future orientation across 33 years. Unpublished Open Access Master's Thesis.Paper 23.http://digitalcommons.uri.edu/theses/23

LIoyd, C.B. (2005). Growing up global: The changing transitions to adulthood in developing countries. Washington D.C.: The National Academies Press.

Lo-oh, J.L. (2017). Positive development in Africa. In Padilla-Walker, L.M. \& Nelson, L.J. (eds.), Flourishing in emerging adulthood: Positive development during the third decade of life. Oxford: Oxford University Press.

Lo-oh, J.L. (2016). The role of social support in the future orientation of emerging adults in Cameroon. European Journal of Research in Social Sciences, 4(7), 43-54.

Lo-oh, J.L. (2012). Self-perceived adult status among emerging adults in the developing world: The Cameroon example. Hull Journal of Educational Advancement, 1(1), 1-9.

Lo-oh, J.L. (2009). Youth transitions to adulthood: Changes, trends and implications for preparing the next generation of Africa. CODESRIA, $3 \& 4,33-42$.

Manzi, C., Vignoles, V.L. \& Regalia, C. (2010). Accommodating a new identity: Possible selves, identity change and across two life transitions. European Journal of Social Psychology, 40(6), 970-984. 
Markus, H., \& Nurius, P. (1986). Possible selves. American Psychologist, 41, 954-969.

McCabe, K., \& Barnett, D. (2000). First comes work, then comes marriage: Future orientation among AfricanAmerican Young Adolescents. Family Relations, 49, 63-70.

Messersmith, E.E. \& Schulenberg, J.E. (2008). When can we expect the unexpected? Predicting educational attainment when it differs from previous expectations. Journal of Social Issues, 64(1), 195-211.

Nsamenang, A.B. (2016). The Developmental psychology of human diversity. Bamenda: HDRC Publications.

Nsamenang, A.B. (2007). African youth struggles into the local and global workforces. Paper presented at the Jacobs Foundation Conference on the "Transition from School to Work", Marbach Castle, April 12-14 2007.

Nsamenang, A.B. (2002). Adolescence in sub-Saharan Africa: An image constructed from Africa's triple inheritance. In B.B. Brown, R. Larson, \& T.S. Saraswathi (Eds.), The world's youth: Adolescence in eight regions of the globe. London: Cambridge University Press.

Nurmi, J.E. (2004). Socialization and self-development: Channeling, selection, adjustment and reflection. In R.M. Lerner \& L. Steinberg (Eds.), Handbook of adolescent psychology. Hoboken, NJ: Wiley.

Nurmi, J.E. (1994). The development of future orientation in a lifespan context. In Z. Zaleski, Z. Zaleski (Eds.), Psychology of future orientation. 20-616 Lublin Poland: Wydawnictwo Towarzystwa Naukowego Katolickiego Uniwersytetu Lubelskiego.

Nurmi, J.E. (1991). How do adolescents see their future? A review of the development of future orientation and planning. Developmental Review, 11, 1-59.

Nurmi, J.E. (1989). Development of orientation to the futureduring early adolescence: A four-year longitudinalstudy and two cross-sectional comparisons. International Journal of Psychology, 24, $195-$ 214.

Ofosu-Kusi, Y. (2014). Children's motivation for migration and engagement in labour in the city of Accra. In Michael Bourdillon \& Georges M. Mutambwa (Eds.), The place of work in African childhoods (La place du travail chez les enfants africains). Dakar: CODESRIA

Oyserman, D. \& Markus, H. (1990). Possible selves and delinquency. Journal of Personality and Social Psychology, 59, 112-125.

Peetsma, T. T. (2000). Future time perspective as a predictor of school investment. Scandinavian Journal of Educational Research, 44(2), 177-192.

Raffaelli, M. \& Koller, S.H., (2005). Future expectations of Brazilian city street youth. Journal of Adolescence, 28, 249-262.

Richter, L. \& Panday, S., (2006). Youth conceptions of the transition to adulthood in South Africa: Barriers and opportunities. Feature: Sexuality in Africa Magazine.

Seginer, R. (2009). Future orientation: Developmental and ecological perspectives. New York: Springer.

Seginer, R., Vermulst, A., \& Shoyer, S. (2004). The indirect link between perceived parenting and adolescent future orientation: A multiple-step model. International Journal of Behavioural Development, 28, 365 378.

Seginer, R. \& Halabi-Kheir, H. (1998). Adolescent passage to adulthood: Future orientation in the context of culture, age and gender. International Journal of Intercultural Relationships, 22(3), 309-328. 
Seginer, R. (1988). Social milieu and future-orientation: The case of kibbutz vs. urban adolescents. International Journal of Behavioural Development, 11, 247-273.

Seijts, G. H. (1998). The importance of future time perspective in theories of work motivation. Journal of Psychology: Interdisciplinary and Applied, 132(2), 154-168.

Serpell, R. (1994). An African social ontogeny: Review of A. Bame Nsamenang (1992). Human development in cultural context: A third world perspective. Cross-cultural Psychology Bulletin, 28 (1), 17-21.

Settersten, R.A. (2006). Becoming adult: Meanings and markers for young Americans. In P. Carr \& M. Kefalas (Eds.), Coming of age in America. Chicago: University of Chicago Press.

Shanahan, J.M., Porfeli, E. \& Motimer, J., (2005). Subjective age identity and the transition to adulthood: When does one become an adult? In R. Al, Jr. Settersten, F.F. Furstenberg, Jr., and R.G. Rumbaut (Eds.). On the frontier of adulthood: Theory, research and public policy. Chicago: University of Chicago Press.

Shanahan, J.M. (2000). Pathways to adulthood in changing societies: Variability and mechanisms in life course perspective. Annual Review of Sociology, 26, 667-692.

Smith, C. Christofferson, K., Davison, H. \& Herzog, P.S. (2011). Lost in transition: The dark side of emerging adulthood. New York: Oxford University Press.

Sommers, C., \& Gizzi, T. (2001).Predicting adolescents' risky behaviours: The influence of future orientation, school involvement and school attachment. Adolescent \& Family Health, 2, 3-11.

Stauber, B. \& Walther, A., (2002). Young adults in Europe-transitions, policies and social change. In A. Walther \& B. Stauber (Eds.), Misleading trajectories: Integrations policies for young adults in Europe? (pp. 1126). A European Group for Integrated Social Research (EGRIS) Publication. Opladen: Leske and Budrich.

Steinberg, L. (2008). A social neuroscience perspective on adolescent risk-taking. Developmental Review, 28, 78 $-106$.

Steinberg, L. (2001). We know some things: Parent-adolescent relationships in retrospect and prospect. Journal of Research on Adolescence, 11, 1-19.

Steinberg, L., O’Brien, L., Cauffman, E., Graham, S., Woolard, J. \& Banich, M. (2009). Age differences in future orientation and delay discounting. Child Development, 80(1), 28-44.

Snyder, C.R. (2002). Rainbow in the Mind in Psychological Inquiry. Vol 13. No. 4. PP24-275.

Stoddard, S. A., Zimmerman, M. A., \& Bauermeister, J. A. (2011). Thinking about the future as a way to succeed in the present: A longitudinal study of future orientation and violent behaviours among African American youth. American Journal of Community Psychology, 48(3-4), 238-246.

Thorsen, D. (2014). Work opportunities and frictions for ruralchild migrants in West African cities. In Michael Bourdillon \& Georges M. Mutambwa (Eds.), The place of work in African childhoods (La place du travail chez les enfants africains). Dakar: CODESRIA.

Trommsdorff, G. (1983). Future orientation and socialization. International Journal of Psychology, 18, 381-406.

Wang, B., Li, X., Barnett, D., Zhao, G., Zhao, J., \& Stanton, B. (2012). Risk and protective factors for depression symptoms among children affected by HIV/AIDS in rural China: A structural equation modelling analysis. Social Science \& Medicine, 74(9), 1435-1443.

Webley, P., \& Nyhus, E. K. (2006). Parents' influence on children's future orientation and saving. Journal of Economic Psychology, 27(1), 140-164. 
Young Lives (2016). Towards a better future? Hopes and fears from young lives. Oxford: Oxford Department for International Development.

Zhang, J., Zhao, G., Li, X., Hong, Y., Fang, X., Barnett, D. \& Zhang, L. (2009). Positive future orientation as a mediator between traumatic events and mental health among children affected by HIV/AIDS in rural China. AIDS Care: Psychological and Socio-medical Aspects of AIDS/HIV, 21(12), 1508-1516.

Zimba, R.F. (2002). Indigenous conceptions of childhood development and social realities in southern Africa. In H. Keller, Y.P. Poortinga \& A. Scholmerish (Eds.), Between culture and biology: Perspectives on ontogenetic development. Cambridge: Cambridge University Press. 